\title{
Studi Selera Generasi Muda Usia 18-35 Tahun terhadap Dekorasi Hotel di Jawa Timur
}

\author{
Chrysan Adi Putri ${ }^{1}$, Prasetyo Wahyudie ${ }^{2}$ \\ ${ }^{1,2}$ Desain Interior, FTSP, Institut Teknologi Sepuluh Nopember, Surabaya 60111, Indonesia \\ ${ }^{1}$ chrysanadiputri@gmail.com, ${ }^{2}$ prasetyo@interior.its.ac.id
}

\begin{abstract}
ABSTRAK
Hotel merupakan suatu akomodasi yang menyediakan jasa penginapan berupa kamar yang disewakan, makanan dan minuman serta fasilitas lainnya untuk umum yang dikelola secara komersial. Semakin berkembangnya jaman, semakin banyak bidang pariwisata yang berkembang, akan semakin banyak hotel yang dibutuhkan, tidak hanya di kota-kota besar namun juga di kota-kota kecil. Kota Kediri merupakan salah satu kota dengan pilihan pariwisata mulai dari wisata alam hingga wisata sejarah. Saat inisemakin banyak wisatawan yang mayoritas generasi muda, namun tidak banyak hotel yang menyediakan fasilitas ataupun dekorasi yang variatif yang mampu menarik bagi mereka.

Riset ini bertujuan untuk mengetahui selera generasi muda terhadap sebuah hotel. Mulai dari dekorasi dan jenis furnitur yang nyaman digunakan sehingga mampu menciptakan desain yang menarik minat kalangan generasi muda. Metode riset yang digunakan meliputi pengumpulan data studi pustaka guna mendapatkan variabel-variabel yang menjadi tolak ukur permasalahan dan penyebaran angket atau kuisioner secara online.

Dari hasil penelitian, didapatkan bahwa generasi muda menyukai tema rustik yang menampilkan kesan natural. Generasi muda yang memiliki karakter suka mencoba hal yang baru, dan menginginkan adanya fasilitas yang menyenangkan. Selain itu kualitas pelayanan yang diberikan oleh hotel akan mempengaruhi pengunjung untuk mau kembali lagi ke hotel tersebut.
\end{abstract}

Kata kunci:dekorasi, hotel,generasi muda,Kediri

\section{ABSTRACT}

Hotel is a accommodation provides lodging services form is rent rooms, food and beverages and the other facilities for the public who managed commercially. In this modern era, the more the field of tourism is growing will be more hotel needed, not only in big cities but also in small towns. Kediri City is one of the city with the choice of tourism from natural tourism tour to history. This time the more tourists that the majority of the young generation, but not many hotel that provides the facilities or decorations are nonetheless capable of interesting for them.

This research aims to know tastefully of the young generation of a hotel. Start from the decoration and the type of furniture that is comfortable to use and thus are able to create a design attracted the interest of the young generation. Research methods used include library study data collection in order to get the variables to measure the problems and the spread of questionnaires or questioner online.

From the results of research, obtained that the young generation like the theme that rustic displays the natural impression. The young generation who have characters like trying new things, and wants a pleasant facilities. Besides that the quality of services provided by the hotel will affect the visitors to want to come back again to the hotel.

Key Words: Decoration, Hotel, the young generation, Kediri

\section{PENDAHULUAN}

Menurut Menteri Pariwisata, Pos, dan Telekomunikasi (SK no.KM 37/PW.340/MPPT86), hotel merupakan suatu akomodasi yang mempergunakan sebagian ataupun keseluruhan 
bangunan yang menyediakan jasa penginapan berupa kamar yang disewakan, makanan dan minuman serta fasilitas lainnya untuk umum yang dikelola secara komersial. Saat ini pembangunan hotel-hotel baru di Indonesia terus meningkat. Ketua PHRI Jawa Timur M. Soleh mengatakan bahwa pertumbuhan yang cukup signifikan dalam industri perhotelan dan restoran saat ini dikarenakan oleh kemudahan sistem perijinan yang diberikan pemerintah kota, kabupaten dan propinsi di Jawa Timur, sehingga peluang bisnis perhotelan yang cukup menjanjikan ini membuat para investor dan pelaku usaha properti mengambil bagian meraih keuntungan serta meramaikan industri perhotelan [4]

Seiring denganperkembangan jaman, semakin banyak bidang pariwisata yang berkembang. Fenomena yang terjadi pada trend pariwisata, khususnya di dunia saat ini adalah pesatnya pertumbuhan wisata kota (Rai Utama, 2015, p.6). Menurut Iwan Wahidin(2014), masa remaja adalah masa yang penuh dengan rasa keingintahuan. mereka menyukai hal-hal yang baru, mencari pengalaman dan menyukai tantangan. Dengan karakteristik tersebut, menunjukkan bahwa generasi muda ternyata menyukai dunia pariwisata.

Kota Kediri merupakan salah satu kota dengan pilihan pariwisata mulai dari wisata alam hingga wisata sejarah. Gunung Kelud adalah salah satu wisata alam Kota Kediri yang menarik bagi wisatawan. Menurut legenda, asal-usul Gunung Kelud bukan berasal dari proses alami. Gunung Kelud adaakibat pengkhianatan cinta seorang putri bernama Dewi Kilisuci terhadap dua raja sakti bernama Mahesa Suro dan Lembu Suro. Dikisahkan Dewi Kilisuci anak putri Jenggolo Manik yang terkenal akan kecantikannya dilamar oleh dua orang raja. Namun yang melamar bukan dari bangsa manusia, karena yang satu berkepala lembu bernama Raja Lembu Suro dan satunya lagi berkepala kerbau bernama Mahesa Suro.

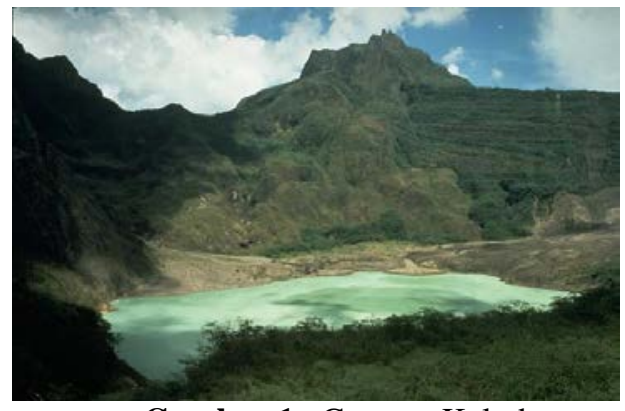

Gambar 1. Gunung Kelud Sumber :

https://id.wikipedia.org/wiki/Berkas:Kelut.jpg

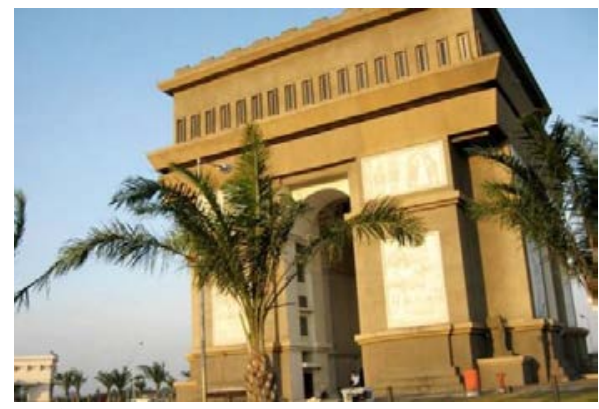

Gambar 2.Monumen Simpang Lima

Sumber :http://www.tempatwisataid.com/wpcontent/uploads/2014/09/Tempat-Wisata-KediriMonumen-Simpang-Lima-Kediri.jpg

Selain itu adapula Monumen Simpang Lima yang menjadi simbol dari kota Kediri. Monumen ini merupakan salah satu tempat wisata baru di Kediri yang memiliki daya tarik tersendiri bagi wisatawan, sehingga banyak wisatawan terutama anak muda yang sering mengunjungi tempat tersebut untuk menikmati keindahan kota Kediri atau hanya untuk sekedar nongkrong sambil bercengkrama dengan teman ("Tempat Wisata di Kediri Yang Menarik Untuk Dikunjungi”, n.d.). Terdapat ukiran atau relief yang mengilustrasikan cerita rakyat yang dulunya pernah berkembang di Kota Kediri pada dinding monumennya.Daya tarik lainnya pada monumen ini adalah pemadangan matahari terbenam, dimana monumen ini berada di tengah jalan besar yang dikelilingi jalan-jalan besar dan sawah sehingga ketika menjelang sore hari banyak dikunjungi oleh pasangan muda. Tempat wisata lain yang tidak kalah menariknya adalah wisata sejarah petilasan Joyoboyo yang merupakan peninggalan jaman kerajaaan Majapahit. 
Sehingga dengan adanya lokasi-lokasi wisata yang semakin beragam, nantinya akan muncul hotel-hotel baru yang memanfaatkan peluang bisnis tersebut. Dalam dunia pariwisata saat ini, terjadi pergeseran usia wisatawan yang semula di atas 35 tahun, dan kini didominasi wisatawan usia muda [7].

Pada kenyataannya, dengan banyaknya wisatawan yang mayoritas generasi muda, ternyata tidak banyak hotel yang menyediakan fasilitas ataupun dekorasi yang variatif yang mampu menarik bagi kalangan generasi muda. Kondisi tersebut menunjukkan perlunya pemahaman lebih dalam tentang bagaimana selera generasi muda saat ini terhadap sebuah hotel,mulai dari dekorasi dan jenis furnitur yang nyaman dan disukai oleh generasi muda sehingga mampu menciptakan desain ruangan yang menarik dan cocok bagi generasi muda.

\section{METODOLOGI}

Tempat yang digunakan sebagai objek penelitian adalah hotel di Kediri dan waktu penelitian dilaksanakan pada bulan Oktober-November 2015. Penelitian dimulai dengan melakukan kajian pustaka untuk mendapatkan pemahaman tentang hotel dan segala fasilitasnya dan juga untuk mendapatkan variabel-variabel yang berpengaruh dalam menentukan daya saing hotel yang menarik bagi generasi muda untuk menginap. Variabel yang didapatkan antara lain: alasan utama menginap di hotel, faktor utama dalam memilih hotel, faktor yang menarik dalam memilih hotel, dekorasi ruangan yang diinginkan generasi muda, faktor yang menarik pengunjung kembali lagi.

Kuesioner disusun berdasarkan variabel yang telah didapatkan serta menggunakan metode skala likert, sehingga variabel-variabel yang dijabarkan dapat menjadi indikatorindikator yang dapat diukur [8]. Dari hasil kuisioner didapatkan jawaban yang diperlukan guna menghasilkan desain interior yang sesuai dengan selera generasi muda yang merupakan target pasar riset ini.

Populasi dalam penelitian ini adalah generasi muda di wilayah Surabaya. Generasi muda di wilayah Surabaya diharapkan mewakili pemikiran generasi muda pada umunya yang akan menjadi calon pengunjung hotel sebanyak 30 orang.

\section{PEMBAHASAN}

\section{A. Alasan Utama Menginap di Hotel}

Pengunjung sebuah hotel biasanya didominasi oleh pengunjung keluarga yang terdiri dari empat golongan yaitu generasi-generasi, remaja, dewasa dan lansia. Menurut hasil riset menunjukkan bahwa pengunjung lebih sering menghabiskan waktu di hotel bersama orang tua dengan persentase terbesar yaitu 53,3\% dari 30 responden seperti yang tertera pada diagram berikut :
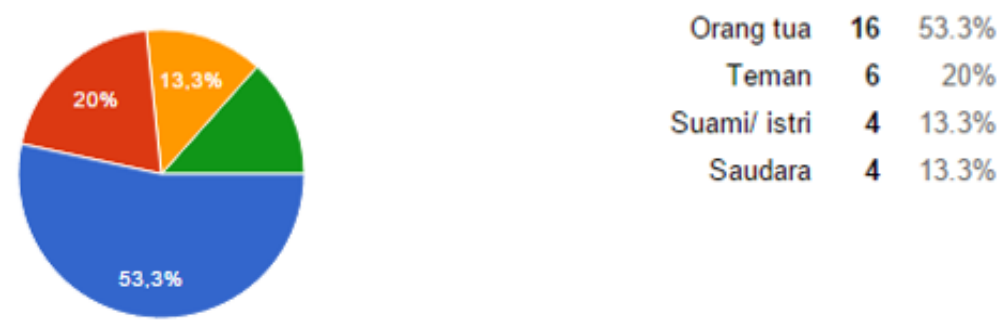

Gambar 1.Orang yang Menemani Pengunjung Menghabiskan Waktu di Hotel. 
Menginap bersama orang tua ternyata lebih sering dilakukan oleh responden karena menginap di hotel lebih sering dilakukan ketika berlibur bersama keluarga. Hal ini dibuktikan dengan presentase $80 \%$ atau setara dengan 24 dari 30 responden menjawab bahwa bermalam saat liburan adalah alasan paling sering yang digunakan untuk menginap di hotel. Karena sebagai bagian dari pariwisata, hotel selalu berlokasi di dekat tempat pariwisata baik dari wisata alam ataupun wisata belanja.
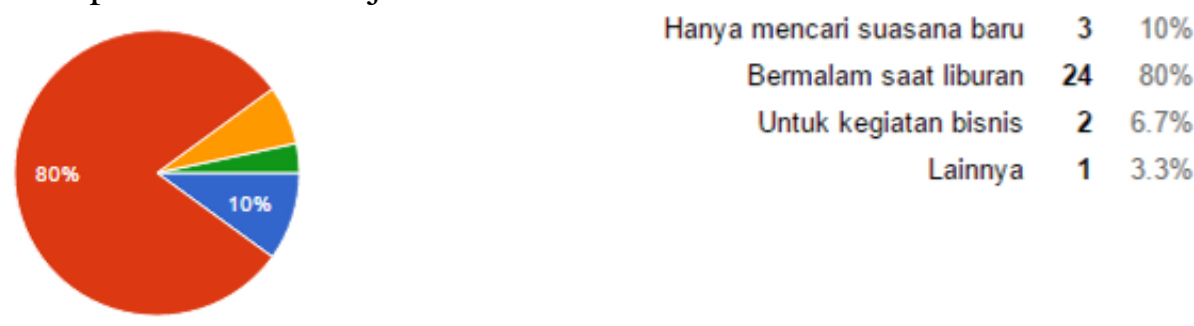

Gambar 2. Alasan Pengunjung Menginap di Hotel.

Dari diagram pie diatas (Gambar 2), 3 dari 30 responden memilih mencari suasana baru menjadi alasan kedua terbanyak untuk menginap di hotel, hal ini biasa dilakukan oleh para eksekutif muda atau karyawan yang lelah dan bosan dirumah. Sedangkan presentase 6,7\% atau 2 orang responden menyatakan menginap di hotel sebagai bagian dari kegiatan bisnis yang merujuk pada pelaksanaan rapat dan bertemu klien di hotel.

Dengan berkembangnya teknologi yang semakin canggih dan mudah, kini generasi muda tidak lagi takut untuk berlibur atau bepergian tanpa orang tua dan lebih suka menghabiskan waktu bersama teman-teman untuk berwisata. Sehingga dunia pariwisata saat ini tidak hanya didominasi oleh keluarga tetapi juga remaja dan paruh baya untuk menghilangkan penat aktivitas sehari-hari.

Sehingga pada perencanaan pembangunan sebuah hotel, strategi pemilihan lokasi sangat penting. Hal tersebut karena lokasi sebuah hotel menentukan banyaknya pengunjung yang datang. Sebuah hotel yang berada di dekat tempat pariwisata akan lebih banyak dipilih oleh pengunjung karena pengunjung dapat langsung beristirahat setelah berpariwisata.

\section{B. Faktor Utama dalam Memilih Hotel}

Dalam memilih sebuah hotel, ada empat faktor utama yang menjadi pertimbangan bagi pengunjung yaitu dekorasi, lokasi, harga dan fasilitas. Keempat faktor tersebut memiliki persentase keutamaan yang berbeda-beda bagi tiap pengunjung. Dari hasil kuisioner didapati bahwa harga menjadi faktor paling utama bagi pengunjung dalam memilih sebuah hotel yang dipilih oleh 14 responden dengan persentase 46,7\%. Faktor harga menjadi prioritas utama karena berkaitan dengan dana yang dimiliki oleh pengunjung. Setiap pengunjung pasti ingin mendapatkan harga yang sesuai dengan kantong mereka sehingga mengetahui harga kamar menjadi hal utama dalam pertimbangan memilih hotel.

Faktor lokasi juga menjadi pertimbangan utama setelah harga karena lokasi hotel menentukan kenyaman dalam berwisata. Biasanya lokasi hotel yang dicari yaitu dengan kriteria terletak di pinggir jalan, dekat wisata belanja atau ditengah kota dengan akses transportasi yang mudah. Sebanyak 12 responden memilih lokasi sebagai faktor utama dalam memilih hotel dengan persentase $40 \%$ sesuai dengan hasil riset kuisioner di bawah ini : 


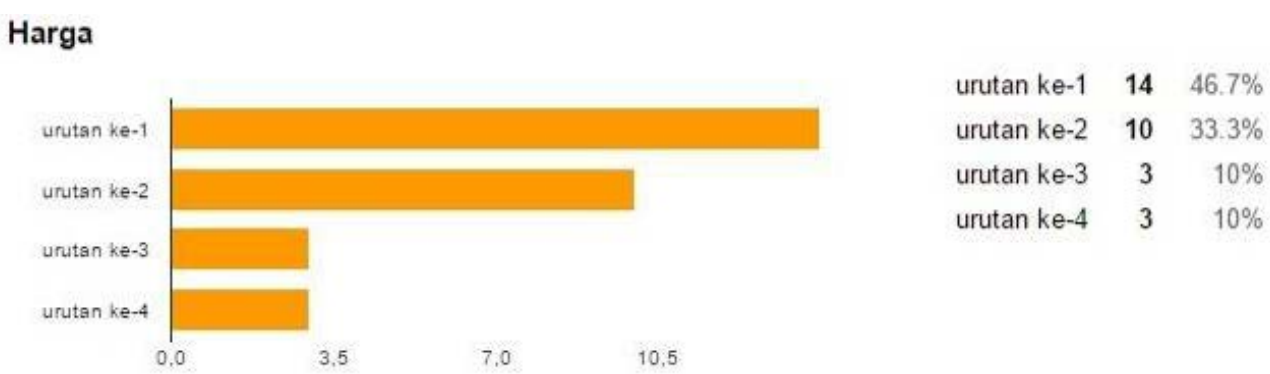

Gambar 3. Pengaruh Faktor Harga dalam Mempengaruhi Pengunjung Memilih Hotel.

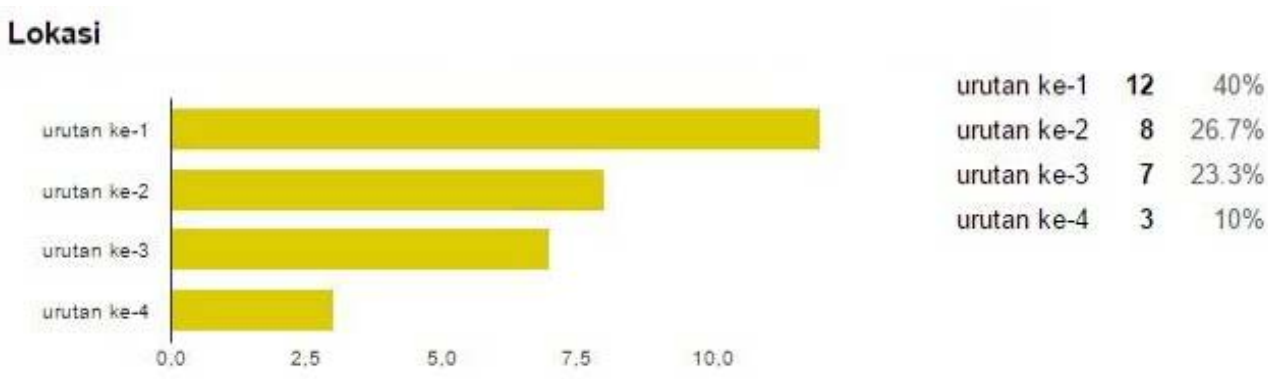

Gambar 4. Pengaruh Faktor Lokasi dalam Mempengaruhi Pengunjung Memilih Hotel.

Kemudian faktor utama ketiga adalah fasilitas yang diberikan setelah harga dan lokasi hotel. Fasilitas yang diberikan menjadi pertimbangan karena berkaitan dengan kenyaman pengunjung. Kenyaman pengunjung didapatkan dari fasilitas non fisik seperti pelayanan staff hotel yang ramah dan fasilitas fisik yang dapat dirasakan pengunjung seperti adanya kolam renang, fitness centre, dan lain sebagainya.

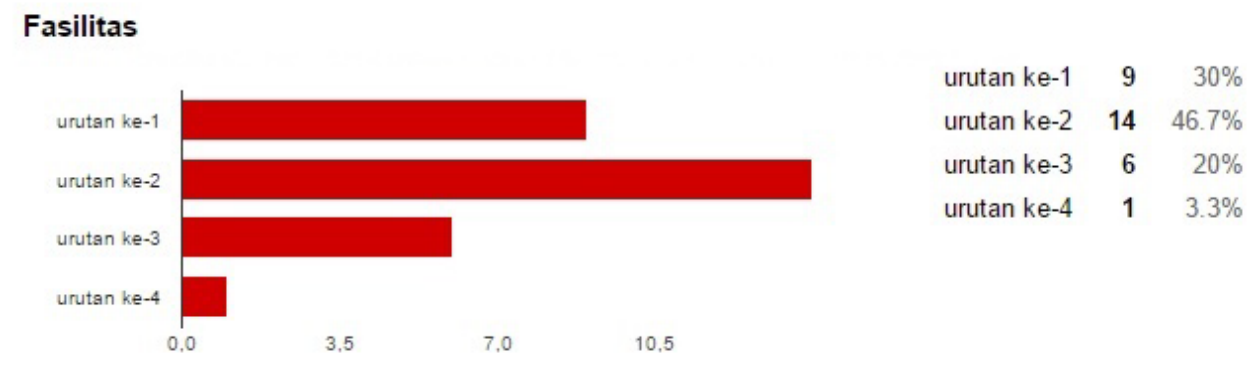

Gambar 5. Pengaruh Faktor Fasilitas dalam Mempengaruhi Pengunjung Memilih Hotel.

Dari keempat faktor tersebut diketahui bahwa faktor dekorasi menjadi pilihan terakhir yang menentukan seseorang memilih sebuah hotel. Hal ini dapat dikaitkan dengan banyaknya dekorasi serupa atau bertema sama yaitu modern minimalis pada hotel-hotel saat ini sehingga pengunjung tidak mengkhawatirkan masalah dekorasi ruangan. Dekorasi juga baru terlihat setelah pengunjung berada di dalam hotel.

Sehingga pada perancangan sebuah hotel, untuk mendapatkan pelanggan lebih banyak sebuah hotel harus menawarkan harga yang menarik. Selain itu, fasilitas yang diberikan seperti fasilitas ruangan maupun fasilitas layanan dari hotel perlu ditingkatkan kualitasnya. Kemudian unsur dekorasi ruangan hotel sebaiknya memiliki sebuah tema secara menyeluruh agar dekorasi lebih terasa dan menjadi satu kesatuan dengan arsitektur hotel. 


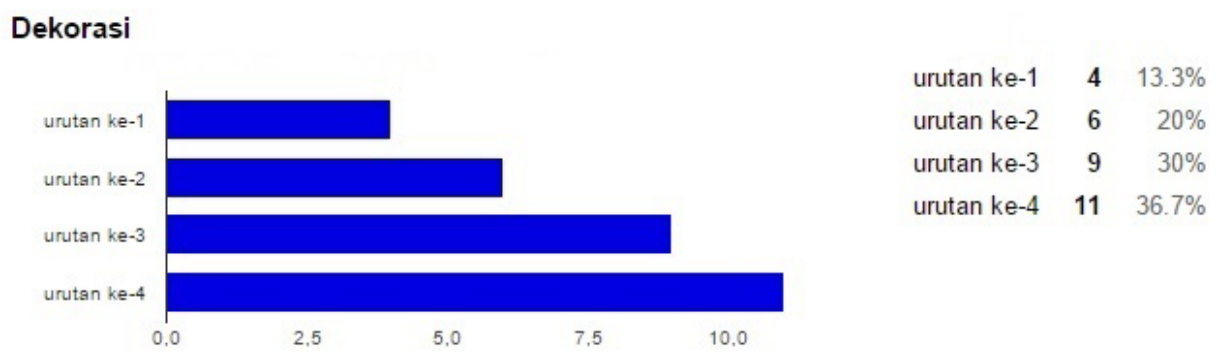

Gambar 6. Pengaruh Faktor Dekorasi dalam Mempengaruhi Pengunjung Memilih Hotel.

\section{Faktor yang Menarik dalam Memilih Hotel}

Ketika seorang pengunjung memilih sebuah hotel, terdapat faktor-faktor penentu yang membuat pengunjung tertarik untuk memilih. Faktor tersebut antara lain dekorasi kamar, arsitektur hotel, dan fasilitas hotel.
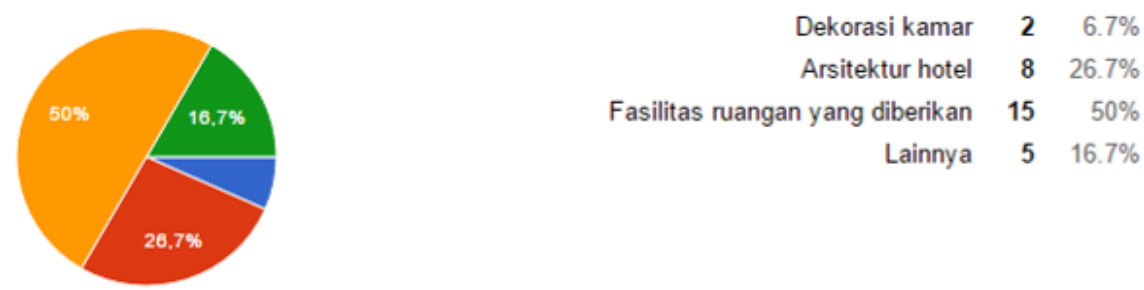

Gambar 7. Faktor yang Menarik Pengunjung dalam Menentukan Pemilihan Hotel.

Hasil riset membuktikan bahwa fasilitas ruangan yang diberikan oleh hotel adalah faktor utama yang menarik perhatian pengunjung generasi muda dengan persentase 50\% atau 15 responden. Fasilitas ruangan yang disediakan oleh pihak hotel umumnya berupa tempat makan dan tempat olahraga. Faktor kedua yang menarik perhatian pengunjung dalam memilih sebuah hotel adalah bentuk arsitektur hotel. Bentuk bangunan sebuah hotel adalah yang paling terlihat dari sebuah hotel, sehingga arsitektural hotel menjadi salah satu faktor penting bagi kesuksesan nama hotel tersebut.
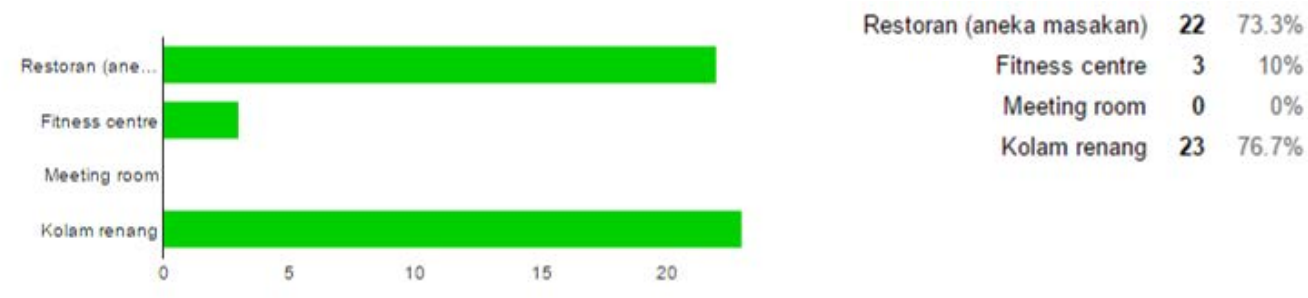

Gambar 8. Fasilitas Hotel yang Menarik Pengunjung.

Dari beberapa pilihan fasilitas yang biasanya terdapat pada sebuah hotel, fasilitas kolam renang dan restoran dengan aneka masakan menjadi fasilitas utama yang banyak diminati oleh pengunjung. Hal ini disebabkan olahraga kolam renang adalah olahraga air yang menyenangkan namun sulit dijangkau karena biaya masuk yang biasanya cukup mahal sedangkan makanan adalah kebutuhan primer bagi manusia, sehingga pengunjung ingin mudah menjangkau tempat makan sehingga tidak perlu untuk khawatir bila merasa lapar. Sehingga pengunjung pasti ingin dapat berenang dengan puas ketika menginap di hotel karena mudah dijangkau dari kamar tidur. Dan dengan persentase 73,3\% dengan 22 orang dari 30 responden menyatakan restoran adalah fasiltas yang paling menarik bagi pengunjung, 
sehingga adanya restoran tentu menjadi fasilitas tambahan utama yang diperlukan bagi setiap hotel selain kolam renang.

Pada sebuah hotel, fasilitas olahraga untuk menunjang kesehatan pengunjung menjadi salah satu keunggulan tersendiri. Fasilitas olahraga yang biasa disediakan adalah kolam renang atau fitness centre. Generasi muda memiliki karakter selalu ingin mencoba hal baru, termasuk dalah bidang olahraga. Dari beberapa pilihan fasilitas olahraga dibawah ini, fasilitas olahraga bowling centre mendapat pilihan terbanyak sebagai sarana olahraga yang ingin dicoba oleh pengunjung hotel generasi muda dengan persentase $50 \%$ atau 15 responden.
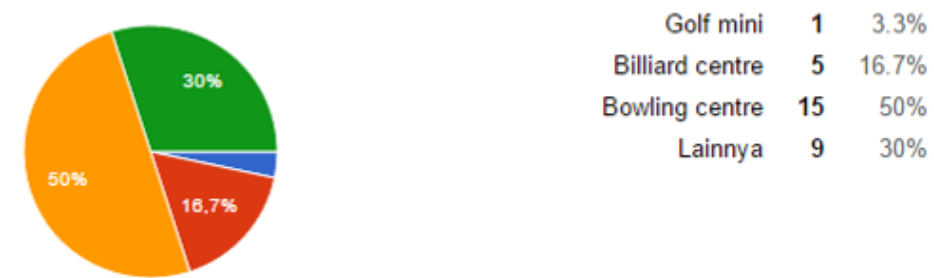

Gambar 9. Fasilitas Olah Raga di Hotel yang Ingin Dicoba Oleh Pengunjung.

Sehingga pada perancangan sebuah hotel, hotel dapat memberikan satu atau lebih fasilitas ruangan tambahan yang dapat membuat pengunjung lebih aktif. Fasilitas yang perlu dipertimbangkan untuk diberikan antara lain fasilitas restoran yang menyediakan bermacam makanan, kolam renang, bowling atau billiard arena. Khusus untuk bowling, masih dipaerlukan kajian khusus, karena menyangkut kebutuhan ruang yang cukup luas serta beaya utilitasnya yang tiinggi. Dengan menambahkan beberapa fasilitas tersebut, hotel dapat memberikan fasilitas yang diinginkan pengunjung.

\section{Dekorasi Ruangan yang Diinginkan Generasi Muda}

Selain itu faktor lainnya yang tidak kalah penting adalah faktor yang membuat betah para pelanggan saat menginap di hotel. Faktor nuansa dekorasi ruangan yang nyaman mendapat 22 suara dari 30 responden sebagai faktor utama yang menentukan kenyaman pengunjung sehingga pengunjung merasa betah menginap di hotel. Faktor nuansa dekorasi ruangan sebelumnya tidak mendapat perhatian sebagai faktor penentu dalan memilih sebuah hotel namun hasil riset membuktikan bahwa nuansa dekorasi ruangan menjadi penentu dalam hal membuat pengunjung betah dengan persentase 73,3\%. Faktor penentu kedua yaitu fasilitas penunjang yang diinginkan pangunjung, seperti kolam renang, restoran dan sebagainya.
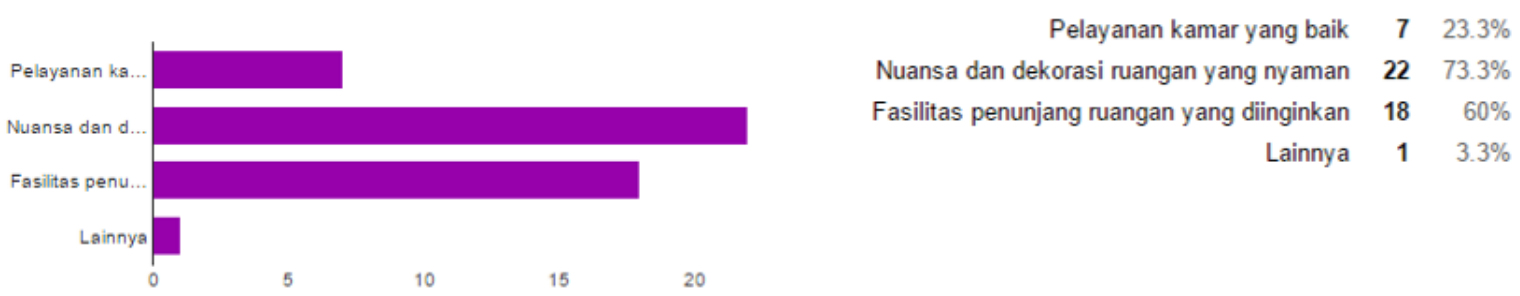

Gambar 10. Faktor yang Membuat Pengunjung Betah saat Menginap di Hotel.

Seperti yang terlihat pada diagram di atas (gambar 10), bahwa nuansa dekorasi ruangan merupakan hal yang membuat pengunjung betah berlama-lama di hotel. Hal ini disebabkan karena sebuah dekorasi ruangan dapat menciptakan nuansa yang mempengaruhi perasaan dan kenyaman pengunjung. Untuk jenis kamar penginapan yang diinginkan oleh pengunjung, 
mayoritas memilih ruangan dengan jendela besar untuk melihat pemandangan keluar. Jendela besar yang menjadi pilihan utama memiliki keunggulan selain dapat melihat pemandangan dengan leluasa juga dapat membuat kesan luas atau tidak terkekang pada pengunjung di dalam ruangan sehingga pengunjung tidak akan merasa penat. Hal ini sangat sesuai dengan karakteristik generasi muda yang suka berpetualang dan tidak suka terkekang.
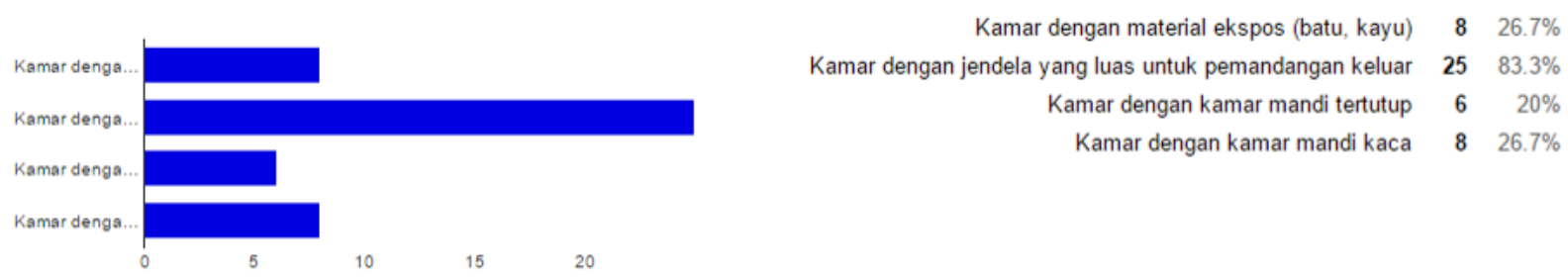

Gambar 11. Jenis Kamar Hotel yang Diinginkan oleh Pengunjung.

Selain tipe kamar, dekorasi desain ruangan juga menjadi penentu dalam membentuk nuansa ruangan. Saat ini sudah banyak hotel dengan dekorasi minimalis dan klasik, sehingga dengan karakteristik generasi muda yang menyukai hal-hal baru dan berbau alam dibutuhkan dekorasi ruangan yang unik. Dengan 12 orang dari 30 responden yang memilih, konsep tema rustik adalah dekorasi yang sesuai dengan selera generasi muda.

Aplikasi tema rustik dapat diaplikasikan pada semua ruangan hotel seperti kamar, restoran, fasilitas olahraga, lobby dan lain-lain. Dekorasi bertema rustik adalah dekorasi dengan penggunaan material alam yang dieskpos seperti batu bata merah pada dinding, dak semen pada plafon dan sebagainya serta nuansa naturan yang didapat dengan penggunaan elemen alam sebagai material utama seperti kayu, dan batu.
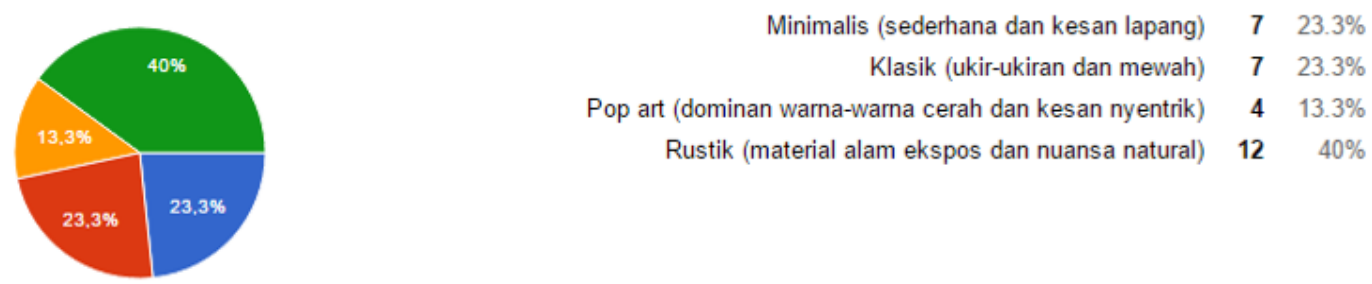

Gambar 12. Tema Desain Interior Hotel yang Diinginkan oleh Pengunjung.
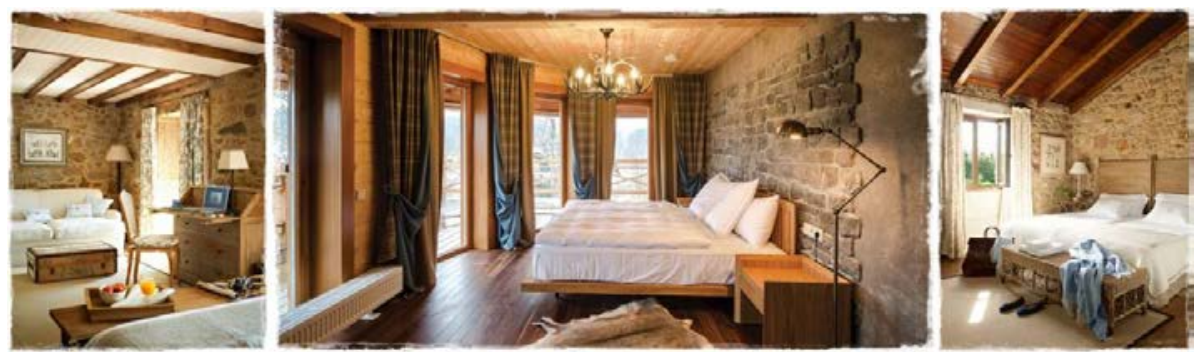

Gambar 13. Dekorasi Rustik pada Ruangan.

Sumber : www.pinterest.com

Selain kamar penginapan, fasilitas restoran yang mendapat suara terbanyak sebagai fasilitas penunjang yang menarik bagi pengunjung harus memperhatikan furnitur yang nyaman bagi pengunjung khususnya generasi muda. Persentase terbesar 53,3\% menyatakan bahwa furnitur meja kayu dengan sofa dan kursi bersandar sebagai furnitur yang paling nyaman untuk menyantap makanan. 

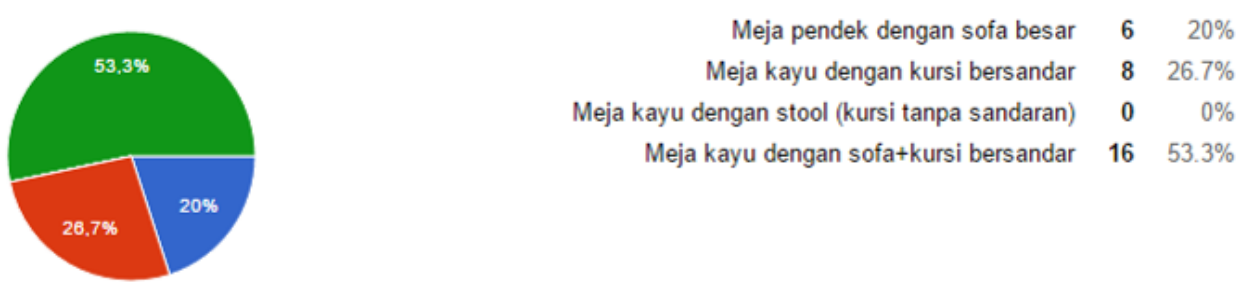

Gambar 14. Fasilitas Restoran Hotel yang Diinginkan Pengunjung.

Perpaduan kursi sofa yang nyaman dan kursi kayu bersandar biasa, pengunjung dapat lebih leluasa memilih untuk duduk dengan posisi nyaman yang dikehendaki. Pada area cafe, penggunaan meja tinggi akan lebih nyaman digunakan oleh pengunjung.

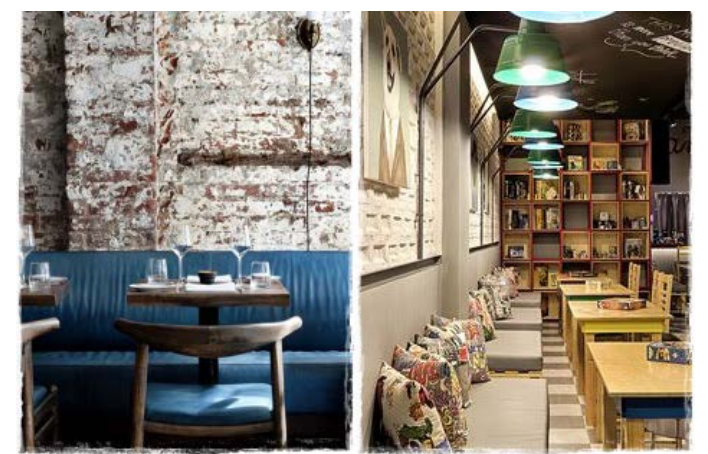

Gambar 15. Contoh Jenis Fasilitas Duduk Restoran yang Diinginkan Pengunjung.

Sumber: www.pinterest.com (2015)

\section{E. Faktor yang Menarik Pengunjung Hotel Kembali Lagi}

Sebuah hotel memerlukan perkembangan untuk dapat melayani pengunjung lebih baik. Dari beberapa faktor penentu yang biasanya menjadi alasan bagi pengunjung untuk menginap kembali di hotel yang sama adalah layanan hotel yang memuaskan dengan persentase $60 \%$.

Layanan hotel yang memuaskan didapatkan dari keramahtamahan pelayan atau staf hotel, kesigapan dalam memenuhi kebutuhan pengunjung dan lain-lain. Pada perancangan hotel, sebaiknya disiapkan beberapa lokasistaff center yang mudah dijangkau oleh pengunjung. Selain itu fasilitas yang menarik juga mampu menarik pengunjung kembali karena fasilitas tersebut merupakan kegiatan yang suka dan ingin dilakukan pengunjung khususnya generasi muda.

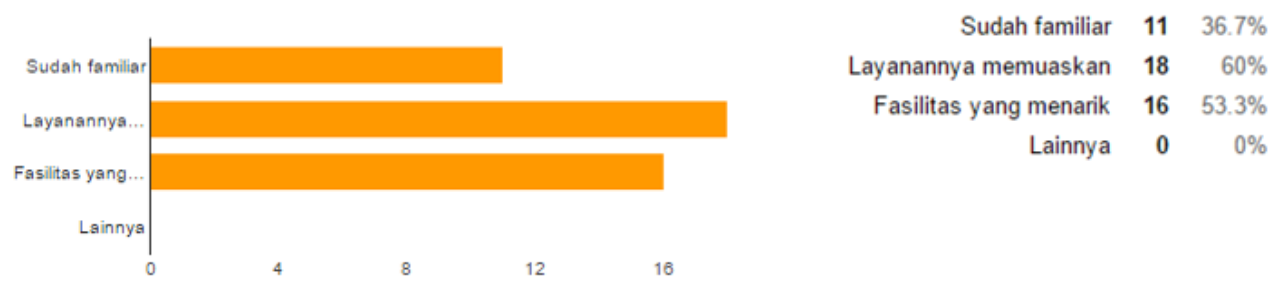

Gambar 16. Faktor yang Menarik Pengunjung Hotel Kembali Lagi.

\section{KESIMPULAN}

Dari hasil riset diatas dapat disimpulkan bahwa desain dekorasi yang sesuai dengan selera generasi muda sebagai target pasar adalah konsep rustik. Konsep rustik menghadirkan nuansa alam dengan material seperti batu dan kayu yang dieskpos, serta penggunaan jendela besar untuk kesan luas dan menyatu dengan alam. Selain itu fasilitas pendukung yang tidak biasa 
seperti bowling center perlu disediakan oleh hotel sebagai alternatif kegiatan yang disukai generasi muda dan mampu memanjakan generasi muda dengan kegiatan baru yang mereka inginkan.

Restoran merupakan fasilitas utama setelah kamar penginapan yang perlu mendapat perhatian. Dengan karakteristik generasi muda yang suka hal baru dan hobi nongkrong, sebaiknya fasilitas restoran diubah menjadi konsep kafe yang lebih nyaman dan tidak terlalu formal. Fasilitas duduk yang akan mendominasi ruangan adalah perpaduan sofa dan kursi kayu bersandar dengan meja kayu tinggi sesuai dengan hasil pilihan terbanyak pada hasil riset.

Sebuah hotel perlu memperhatikan fasilitas yang disediakan bagi pengunjung karena akan mempengaruhi pengunjung dalam memilih hotel tempat menginap. Selalin itu faktor harga yang terjangkau dan layanan yang memuaskan menjadi alasan utama bagi pengunjung untuk memilih dan mau kembali ke hotel yang sama.

\section{PUSTAKA}

[1] http://e-journal.uajy.ac.id/170/3/2TA13053.pdf, Diakses pada tanggal 03 Desember 2015.

[2] http://journal.unair.ac.id/download-fullpapers-Jurnal\%20Adrina.pdf Diakses pada tanggal 03 Desember 2015.

[3]https://docs.google.com/forms/d/1PMihs1YfBP1Gy8xNJtouKcOPer3PTWO8hJKb4gwDf g/viewanalytics

[4]Sary, Yulia. 2014. Pertumbuhan Hotel di Jatim, diakses tanggal 25 Januari 2016, <http://www.rri.co.id/surabaya/post/berita/110792/ekonomi/pertumbuhan_hotel_baru_di jatim.html>

[5] Tempat Wisata di Kediri Yang Menarik Untuk Dikunjungi, diakses pada tanggal 25 Januari 2016, <http://www.tempatwisataid.com/2739/tempat-wisata-di-kediri-yangmenarik-untuk-dikunjungi.html>

[6] Wahidin, Iwan. 2014. Remaja; Perkembangan Fisik, Psikis, dan Kognitif, diakses tanggal 26 Januari 2016 (http://www.slideshare.net/iwanrwahidin/remaja-perkembangan-fisikpsikis-dan-kognitif. Diakses pada 26 Januari 2016 )

[7] Ningcil. 2015. Sebagian Besar Wisatawan Kini Didominasi oleh Anak Muda, diakses pada tanggal 26 Januari 2016, <http://lifestyle.dreamers.id/article/44233/sebagian-besarwisatawan-kini-didominasi-oleh-anak-muda>.

[8] Indarto, Danang. (2012). Pengaruh Gaya Belajar dan Motivasi Berprestasi Siswa Terhadap Prestasi Belajar Praktik Instalasi Listrik di SMK Negeri 2 Yogyakarta”. Prodi Pendidikan Teknik Elektro, FT, UNY.

[9] Sejarah Gunung Kelud|Legenda Asal-Usul Kelud, diakses pada tanggal 25 Januari 2016, $<$ http://wisatabromo.com/sejarah-gunung-kelud> 